\title{
In vitro investigations of Cynara scolymus L. extract on cell physiology of HepG2 liver cells
}

\author{
Gesine Löhr, Alexandra Deters, Andreas Hensel ${ }^{*}$
}

Institute for Pharmaceutical Biology, University of Münster, Germany

\begin{abstract}
The objective of this study was the investigation of a potential influence of artichoke leaf extract (ALE) on the cell physiology and gene expression of phase I/II enzymes of human liver cells HepG2 and investigation on potential cell protective effects against ethanol-induced cell toxicity against HepG2 cells. Cell biological assays under in vitro conditions using HepG2 liver cells and investigation of mitochondrial activity (MTT test), proliferation assay (BrdU incorporation ELISA), LDH as toxicity marker, gene expression analysis by RT-PCR and enzyme activity of glutationtransferase. Artichocke extract, containing $27 \%$ caffeoylquinic acids and $7 \%$ flavonoids induced mitochondrial activity, proliferation and total protein content under in vitro conditions in human liver cells HepG2. These effects could not be correlated to the well-known artichoke secondary compounds cynarin, caffeic acid, chlorogenic acid, luteolin and luteolin-7-O-glucoside. The flavones luteolin and luteolin-7-O-glucoside had inhibitory effects at $100 \mu \mathrm{g} / \mathrm{mL}$ level on HepG2 cells, with luteolin being a significant stronger inhibitor compared to the respective glucoside. Artichoke leaf extract had minor stimulating effect on gene expression of CYP1A2, while CYP3A4, GGT, GPX2, GSR and GST were slightly inhibited. GST inhibition under in vitro conditions was also shown by quantification of GST enzyme activity. Induction of gene expression of CYP1A2 was shown to be supraadditive after simultaneous application of ethanol plus artichoke extract. Artichoke leaf extract exhibited cell protective effects against ethanol-induced toxicity within cotreatment under in vitro conditions. Also $\mathrm{H}_{2} \mathrm{O}_{2}$ damage was significantly inhibited by simultaneous artichoke incubation. Pre- and posttreatments did not exert protective effects. DMSO-induced toxicity was significantly reduced by pre-, post- and cotreatment with artichoke extract and especially with luteolin-7-O-glucoside, indicating a direct interaction with the toxifying agent and an induction of repair mechanisms.
\end{abstract}

Uniterms: Cynara scolymus L. Asteraceae. Artichoke. Liver cells. Cell proliferation. Gene expression.

O objetivo deste estudo foi a investigação de uma potente influência do extrato das folhas da alcachofra (ALE) na fisiologia celular e na expressão gênica de enzimas de fase I/II de células hepáticas humanas HepG2 e investigação no potencial efeito protetor celular em células HepG2 contra toxicidade celular induzida por etanol. Ensaios biológicos de células em condições in vitro usando células de fígado HepG2 e investigação da atividade mitocondrial (teste MTT), ensaio de proliferação, LDH como marcador de toxicidade, análise de expressão gênica por RT-PCR e atividade da enzima glutationa transferase. O extrato da alcachofra, contendo $27 \%$ de ácidos cafeoilquínico e $7 \%$ de flavonóides, induzem a atividade mitocondrial, proliferação e o teor de proteína total em condições in vitro em células hepáticas humanas HepG2. Estes efeitos não podem ser correlacionados aos compostos secundários conhecidos da alcachofra, cinarina, ácido cafeico, ácido clorogênico, luteolina e luteolin-7-O-glicosídeo. As flavonas luteolina e luteolin-7-O-glicosídeo possuem efeitos inibitórios em nível de $100 \mu \mathrm{g} / \mathrm{mL}$ em células HepG2, com a luteonina sendo uma inibidora significativamente mais forte comparada com o respectivo glicosídeo. $\mathrm{O}$ extrato das folhas de alcachofra possui um efeito mínimo da estimulação na expressão gênica de CYP1A2, enquanto CYP3A4, GGT, GPX2, GSR e GST foram sutilmente inibidos. A inibição de GST em condições in vitro também foi mostrada pela quantificação da atividade da enzima GST. Indução da expressão gênica de CYP1A2 mostrou-se supraaditiva após aplicação simultânea do etanol mais o extrato de alcachofra. O extrato das folhas de alcachofra exibiu efeitos protetores celulares frente à toxicidade induzida por etanol em co-tratamento em condições in vitro. Além disso, danos por $\mathrm{H} 2 \mathrm{O} 2$ foram significativamente inibidos

*Correspondence: A. Hensel, University of Münster, Institute for Pharmaceutical Biology, Hittorfstr. 56, D-48149 Münster, Germany. e-mail: ahensel@ uni-muenster.de 
pela incubação simultânea do extrato de alcachofra. Pré e pós-tratamento não exerceram efeitos protetores. Toxicidade induzida por DMSO foi significativamente reduzida por pré, pós e co-tratamento com extrato de alcachofra e especialmente com luteína-7-O-glicosídeo, indicando uma interação direta com o agente toxicante e a indução dos mecanismos de reparo.

Unitermos: Cynara scolymus L. Asteraceae. Alcachofra. Células hepáticas. Proliferação cellular. Expressão gênica.

\section{INTRODUCTION}

Cynara scolymus L. is an herbal medicinal product widely used in functional foods and phytotherapeutics for digestive complaints, adjuvant treatment of moderate hyperlipidaemia and hepato-biliary disorders in traditional European medicine. For review of established clinical use see (ESCOP Monograph, 2003). Traditionally, hepatostimulating effects are described; for review see (Brand, 1992).

The herbal material is phytochemically characterized by caffeoylquinic acids, e.g. chlorogenic acid and 1,5-dicaffeoylquinic acid (cynarin), flavonoids (e.g. luteolin-7-O-glucoside and 7-O-rutinoside) and bitter tasting sesquiterpene lactones (e.g. cynaropicrin). Various aliphatic acids and caffeic acid derivatives are described.

Concerning the mode of action for treatment of hypercholesterinaemia (Brand, 1990) the reduction of elevated serum cholesterol levels by artichoke is due to an inhibition of incorporation of acetate into the nonsaponifiable lipid fraction and thus will reduce cholesterol biosynthesis (Gebhard, 1995; Gebhard, 1996). As assessed by a recent Cochrane review [5] the clinical effects published unto now indicate a clear tendency towards lower serum cholesterol during artichoke therapy. Other benefits as lipid-lowering efficacy are reported, the evidence however is not compelling.

Other traditional uses of artichoke leaf extract are digestive complaints and hepatobiliary disturbances (for review see EScop Monograph, 2003). These indications are due to an increased secretion of bilary substances into bile canali (Matuschowski et al. 1997; Gebhard, 2001), leading to a choleretic effect (Matuschowski et al., 2005). Clinical data on the use of artichoke on this topic are promising and are reviewed in the above mentioned ESCOP monograph. Other traditional uses of artichoke leaf extract are hepatoprotective (Adzet et al., 1987; Preziosi, 1962, Wojcicki, 1978; Gebhard 1997) and liver regenerating effects (Maros et al., 1968).

Because literature does not answer the question on the cellular mode of action concerning hepatoactivity the aim of the following study was the in vitro investigation of artichoke extracts and isolated compounds on cell physiology of human liver cells and to evaluate potential hepatoprotective effects against different exogenous noxes on physiological and gene expression level.

\section{MATERIALS AND METHODS}

\section{General}

Standardized artichoke extract was obtained from Casellamed, Köln, Germany and was derived from a commercialized extract use for Hepar ${ }^{\circledR S L}$ forte by extraction with aliphatic alcohols (Wittemer et al, 2005). This extract contained $27.5 \%$ caffeoylquinic acids with $10.3 \%$ specified as 3-caffeoylquinic acids. The sum of flavonoids in the extract was $7.1 \%$ with $5.8 \%$ of luteolin-7-O-glucosid. Cynarin, chlorogenic acid, caffeic acid, luteolin and luteolin-7-O-glucosid were obtained by Casellamed AG with purity $>95 \%$. If not stated otherwise, biological assays were performed in 3 independent assays in replicates.

\section{Testing on human liver cell line}

HepG2 (ATCCC HB-8065) cell line, clon H20, capable to express phase I and II metabolizing enzymes under standard cell culture conditions, was obtained from Prof. Mersch-Sundermann, University of Giessen, Germany, and was cultured as described previously (Dauer et al., 2003; Hofmann et al., 2007). Cells were routinely grown in low glucose ( $1 \mathrm{~g} / \mathrm{L})$ Dulbecco's Modified Eagle`s Medium (DMEM) with L-glutamine and $25 \mathrm{mM}$ Hepes (PAA, Cölbe, Germany) supplemented with $15 \%(\mathrm{v} / \mathrm{v})$ heatinactivated fetal calf serum and gentamycin $(30 \mu \mathrm{g} / \mathrm{mL})$ in a humidified atmosphere at $37+/-0.5^{\circ} \mathrm{C}, 5 \% \mathrm{CO}_{2}$ (Incubator Binder AG, Germany). The medium was changed every 3-5 days. Test-substances were dissolved at $1 \mathrm{mg} / \mathrm{mL}$ in HepG2-medium (if necessary under addition of DMSO as cosolvent, respective control solutions in the same way) and filtered through $0.2 \mu \mathrm{m}$ cellulose-acetate (Iwaki Glass, Tokyo, Japan).

\section{Cell assays}

Incubation with test compounds occurred over 48 hours: cells were seeded into 96-well cell plates (Greiner, Frickenhausen, Germany) at $1 \times 10^{4}$ cells/well. After 
$24 \mathrm{~h}$, the medium was removed and cells were exposed to 100 and $10 \mu \mathrm{g} / \mathrm{mL}$ of test compounds for $48 \mathrm{~h}$. Cell viability was quantified using the MTT-test according to Mosmann, 1983). Cell proliferation was quantified by BrdU-Incorporation ELISA [18]. Extracytosolic LDH (Porstmann et al., 1985) was quantified by cytotoxicity assay (Roche Diagnostics, Mannheim, Germany). For gene expression analysis, cells were incubated together with test compounds for 24 hours. Total RNA was isolated with Perfect RNA Eukaryotic Mini Kit (Eppendorf, Hamburg) according to the instructions of the manufacturer. The amount of total RNA was estimated by optical density at $260 \mathrm{~nm}$. Equal amounts of RNA were used for reverse transcriptase polymerase chain reaction (RT-PCR) done with TaqMan ${ }^{\circledR}$ Reverse Transcription Reagents ${ }^{\circledR}$ (Applied Biosystems, Darmstadt). Real-Time-PCR was carried out using the TaqMan ${ }^{\circledR}$ Universal PCR Master Mix and specific TaqMan ${ }^{\circledR}$ gene expression assays (from Applied Biosystems, Darmstadt, Germany):

\begin{tabular}{cc}
\hline genes & Assay ID \\
\hline GPX & Hs00702173_s1 \\
CYP1A2 & Hs00167927_m1 \\
CYP3A4 & Hs00604506_m1 \\
GGT1 & Hs00359124_g1 \\
GSR & Hs00167317_m1 \\
GST & Hs00542846_m1 \\
GAPDH & Hs99999905_m1 \\
\hline
\end{tabular}

For GST no distinct isoforms were screened but the protein coding gene type GST SCLo6A1 from the HGNC 23613 primary source with a validated RefSeq status from human gene identification number Hs.388874 from chromosome No. 5 Matuschowsky et al., 1997). Glyceraldehyd-3-phosphate dehydrogenase was used as the internal reference. Data were quantified by the 7300 Real-time PCR System RQ Study software (Applied Biosystems, Darmstadt). Gene expression was monitored in 3 independent assays.

\section{Protein biochemistry}

Protein isolation: Adherent cells were washed two times with ice cold water, followed by treatment with lyses buffer (NaPP buffer, $50 \mathrm{mM}$, pH 6.8, 5\% SDS, $40 \mathrm{mM}$ DTT, 5mM EDTA, 5 mM EGTA, 15\% glycerine, 0.1\% Triton $\left.{ }^{\circledR} X-100\right)$. Cells were harvested, transferred into a tube and lysed by sonication for $3 \times 10 \mathrm{sec}$. Supernatant was used after centrifugation (12.000xg) for protein determination according to (Lowry et al., 1951). GST was determined using the GST determination of Novagen (San Diego, U.S.A) (Suzuki et al., 2003).

\section{RESULTS}

An artichocke leaf extract (ALE) containing 27\% caffeoylquinic acids and 7\% flavonoids (Wittemer et al, 2005) significantly increased the mitochondrial dehydrogenase activities of human liver HepG2 after $48 \mathrm{~h}$ incubation time at a $100 \mu \mathrm{g} / \mathrm{mL}$ level, while lower doses were ineffective (Fig. 1A). This was confirmed by the results of proliferation test: ALE significantly increased proliferation rate at doses of $100 \mu \mathrm{g} / \mathrm{mL}$ to about $130 \%$ proliferation, and at $10 \mu \mathrm{g} / \mathrm{mL}$ to $120 \%$; lower doses were ineffective (Fig. 1B). Additionally a significant increase in protein content in treated HepG2 cells was measured: ALE at $100 \mu \mathrm{g} / \mathrm{mL}$ significantly induced the protein content of the cells to about $130 \%$ (data not shown), reflecting the increase in cell number and energy turn over.

A

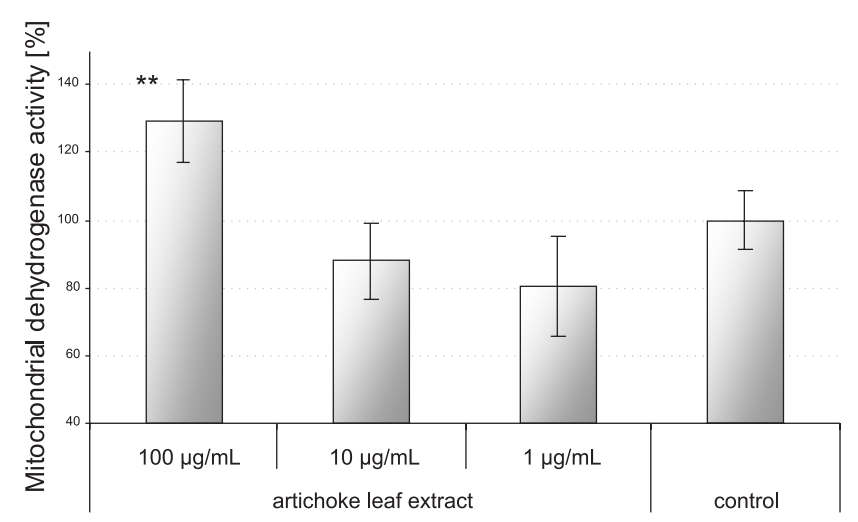

B

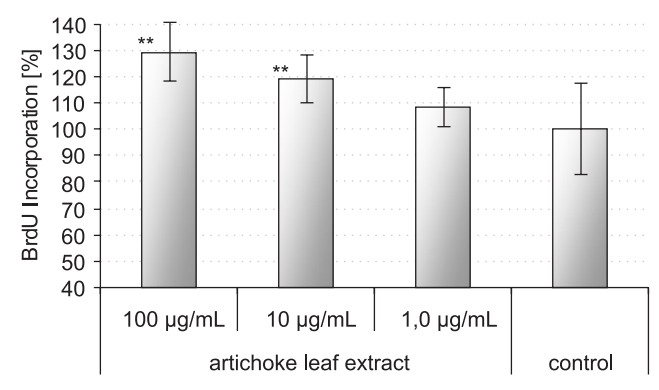

FIGURE 1 - Influence of artichoke leaf extract (ALE) at 1, 10 and $100 \mu \mathrm{g} / \mathrm{mL}$ level on mitochondrial dehydrogenase activity (A) and mitotic cell proliferation (B) of HepG2 cells after 48 hours incubation. Mitochondrial activity determined by MTT test, proliferation determination by BrdU incorporation ELISA. The bars represent standard errors SD from 3 independent experiments with $\mathrm{n}=10$ replicates each with $* p<0.05$, ${ }^{* *} p<0.01$ compared to the untreated control group. 
No necrotic and apoptotic cytotoxicity of ALE was observed within the test range of 1 to $100 \mu \mathrm{g} / \mathrm{mL}$ as measured by $\mathrm{LDH}$ determination and inspection on apoptotic bodies.

To investigate the influence of isolated artichoke compounds on HepG2 cells reference compounds luteolin, luteolin-7-O-glucosid, caffeic acid, chlorogenic acid and cynarin were tested at 100,10 and $1 \mu \mathrm{g} / \mathrm{mL}$ level. Within MTT assay cynarin, chlorogenic acid and caffeic acid did not exhibit any significant effect. Luteolin and luteolin-7$O$-glucosid at $100 \mu \mathrm{g} / \mathrm{mL}\left(3.5 \times 10^{-7} \mathrm{resp} .2 .3 \times 10^{-7} \mathrm{~mol} / \mathrm{L}\right)$ significantly decreased mitochondrial activity (Fig. 2A), related to the calculation of absolute amounts of $100 \mu \mathrm{g} / \mathrm{mL}$ of both compounds. Also when the measured data were normalized to equimolar concentrations $\left(3.5 \times 10^{-7} \mathrm{~mol} / \mathrm{L}\right.$ Luteolin with $84 \%$ inhibition, $3.5 \times 10^{-7} \mathrm{~mol} / \mathrm{L}$, luteolin7-O-glucoside with $54 \%$ inhibition) significantly higher inhibition of mitochondrial activity was obvious for luteolin compared to the respective glycoside. This was also reflected within the respective proliferation assays (Fig. 2B). The inhibitory effect of the flavone-glucosid was significantly lower than that of the free aglycon luteolin.

The mRNA expression of different phase I and II enzymes of HepG2 cells was determined by quantitative RT-

$\mathbf{A}$

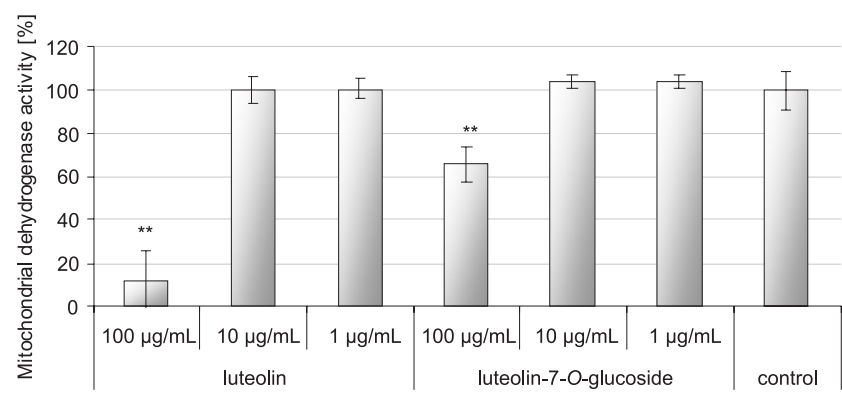

B

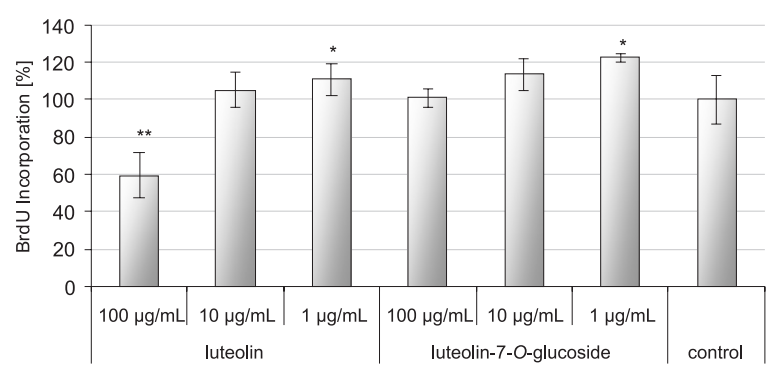

FIGURE 2 - Influence of luteolin and luteolin-7-O-glucoside at $1,10,100 \mu \mathrm{g} / \mathrm{mL}$ on mitochondrial dehydrogenase activity (A) and mitotic cell proliferation (B) of HepG2 cells after 48 hours of incubation. Mitochondrial activity was determined by MTT test, proliferation was determined by BrdU incorporation ELISA. The bars represent SD from independent assay with $\mathrm{n}=10$ replicates with $* p<0.05, * * p<0.01$ compared to the untreated control group.
PCR after a $24 \mathrm{~h}$ incubation time of cells with and without ALE in serum-free media. Gene expression was monitored in 3 independent assays for glutathione-S-transferase GST, glutathionperoxidase GPX, glutathionreductase GSR, $\gamma$ glutamyltransferase GGT1 and the cytochrome P450 isoforms CYP1A2 and CYP3A4. These CYPs were selected because CYP3A4 is the main hepatic cytochrom (about $30 \%$ ) beside CYP1A2 (about 10 to $12 \%$ ). Measured test values were related to the expression of the endogenous control glycerol-3-phosphate dehydrogenase (GAPDH). mRNA expression for CYP1A2 was slightly increased in the presence of artichoke extract ALE $(100 \mu \mathrm{g} / \mathrm{mL})$ to 1.76 $+/-2.4$. Because of the high variability this effect is assessed not to be significant. Significant inhibition of gene expression by ALE was seen for CYP3A4 $(0.23+/-0.39)$, for GGT1 $(0.59+/-0.21)$, for GPX2 $(0.50+/-0.30)$, for $\operatorname{GSR}(0.72+/-0.23)$ and GST $(0.22+/-0.28)$.

The inhibition of glutathione-S-transferase GST gene expression was confirmed by determination of the respective enzyme activity. Therefore HepG2 cells were incubated with ALE $(100,10 \mu \mathrm{g} / \mathrm{mL})$ for $48 \mathrm{~h}$. Total protein was isolated from cell lysate and GST activity was determined after conjugation of 1-chloro-2,4-dinitrobenzene CDNB to endogenous GST. GST activity was calculated relative to the total cell protein content against a GST calibration curve in ALE-treated cells and untreated control. As shown in Fig. 3 ALE inhibited GST activity in a dose-dependent manner.

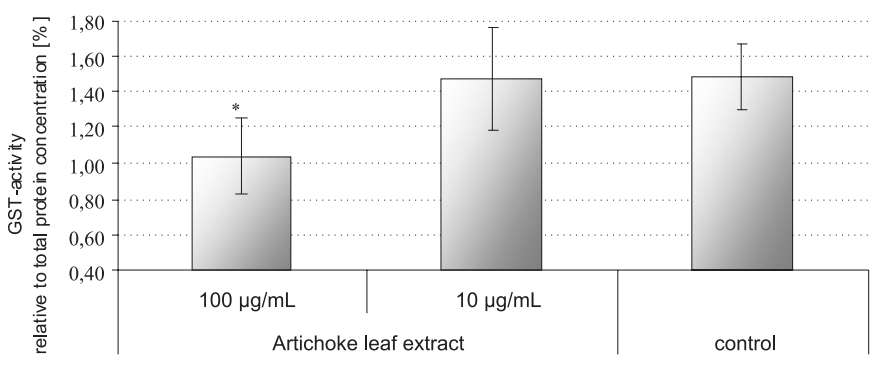

FIGURE 3 - Concentration-dependent inhibition of glutathioneS-transferase (GST) in HepG2 cells after $48 \mathrm{~h}$ treatment with ALE relative to the total protein concentration. The bars represent $\mathrm{SD}$ with $\mathrm{n}=10$ replicates $* p<0.05$.

Summarizing at this point, artichoke extract is assessed to have stimulating activity on the proliferation and the energy turn-over of liver cells, accompanied by effects on metabolising enzymes.

In order to investigate if artichoke extract has also anti-toxic effects against exogenous chemicals, ALE was tested as cytoprotective activity against the toxifying effects of ethanol (marker for unspecific enzyme toxicity), hydrogenperoxide (oxidative toxicity) and dimethylsulfo- 
xid (necrotic toxicity). In a preliminary study the respective concentrations and incubation times were verified to induce a cell toxicity, equivalent to about $50 \%$ reduction of MTT activity. Ethanol was used in the following studies at a 25 to $50 \mathrm{mM}$ level, $\mathrm{H}_{2} \mathrm{O}_{2}$ at 1 to $10 \mathrm{mM}$, and DMSO at 3.5 and $5 \%$ concentration over a 6 to 24 hours incubation time.

As shown in Table I, cotreatment of HepG2 cells with ALE $(100 \mu \mathrm{g} / \mathrm{mL})$ and ethanol $(25$ and $50 \mathrm{mM})$ for 48 hours showed a significant protective effect. Also at $10 \mu \mathrm{g}$ level the respective data showed (not significant) tendencies towards cytoprotective effects.

Also cotreatment of HepG2 cells with ALE $(100 \mu \mathrm{g} / \mathrm{mL})$ and $\mathrm{H}_{2} \mathrm{O}_{2}(1,5,10 \mathrm{mM})$ for 24 hours showed a significant protective effect against the low-dose hydrogen peroxide induced toxicity: while only minor antioxidative effects of ALE were seen against strong cell damage induced by $10 \mathrm{mM} \mathrm{H}_{2} \mathrm{O}_{2}$, clear effects of ALE were observed against $5 \mathrm{mM} \mathrm{H}_{2} \mathrm{O}_{2}$.

Coincubation of HepG2 cells with DMSO (3.5 and $5 \%)$ and ALE for 48 hours $(10,100 \mu \mathrm{g} / \mathrm{mL})$ indicated reduced DMSO-induced toxicity at the $100 \mu \mathrm{g} / \mathrm{mL}$ level, while lower doses did not protect from DMSO-mediated cell toxicity.

Similar test systems, but with pre- and postincubation of cells with ethanol, $\mathrm{H}_{2} \mathrm{O}_{2}$ or DMSO prior or after an ALE-treatment, did not reduce the toxic effects of the chemicals towards HepG2 cells.

In addition to these experiments with artichoke extract, a potential cytoprotective effect of the flavonole reference compounds luteolin and luteolin-7-O-glucoside was investigated against DMSO as exogenous stress fac- tor. For that purpose one cell group, serving as a control, was treated with DMSO 10\%. Proliferation behaviour of this group - with a significantly reduced vitality in contrast to an untreated control - was calculated as $100 \%$. Coincubation of two cell groups with luteolin + DMSO 10\% resp. luteolin-7-O-glucoside + DMSO 10\% indicated that the flavone-glycoside significantly protects cells against DMSO-related toxicity (Fig. 4).

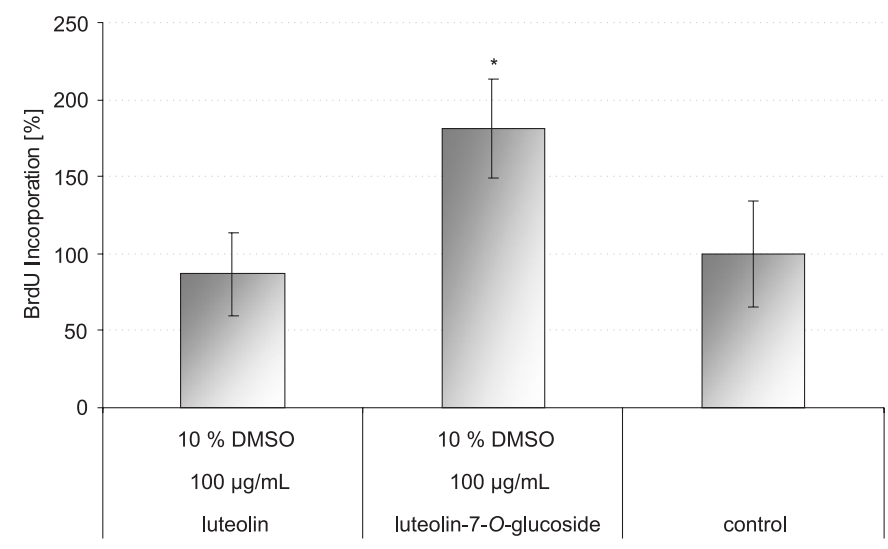

FIGURE 4 - Proliferation (BrdU-ELISA) of HepG2 cells within $48 \mathrm{~h}$ cotreatment with DMSO $10 \%$ and $100 \mu \mathrm{g} / \mathrm{mL}$ luteolin $(0.35$ $\mu \mathrm{M} / \mathrm{mL})$ resp. luteolin-7-O-glucoside $(0.22 \mu \mathrm{M} / \mathrm{mL}) .{ }^{*} p<0.05$ compared to the DMSO $10 \%$ control group.

For investigation of the cytoprotective effects of ALE against ethanol-induced cell damage the mRNA expression of different phase I and II liver enzymes was determined after 3 different treatment cycles of HepG2 cells over a $24 \mathrm{~h}$ incubation time (pre-, post- and cotreatment

TABLE I - Influence of different pre-, post- and cotreatment regimes of ethanol, hydrogen peroxide and DMSO in combination with artichocke extract (ALE) on mitochondrial activity of HepG2 cells. Mitochondrial activity was determined by MTT test and measured values were related to the respective control groups $(100 \%)$. ${ }^{* *} p<0.01 . \Rightarrow$ : followed by treatment with compounds indicated

\begin{tabular}{llcc}
\hline Type of treatment of HepG2 cells & & & Mitochondrial Activity (\%) \\
\hline Ethanol $50 \mathrm{mM} ; 48 \mathrm{~h}$ & $\Rightarrow$ & ALE $100 \mu \mathrm{g} ; 48 \mathrm{~h}$ & $313+/-38 \% * *$ \\
Ethanol $25 \mathrm{mM} ; 48 \mathrm{~h}$ & $\Rightarrow$ & ALE $100 \mu \mathrm{g} ; 48 \mathrm{~h}$ & $178+/-77 \% * *$ \\
Ethanol $50 \mathrm{mM} ; 48 \mathrm{~h}$ & $\Rightarrow$ & ALE $10 \mu \mathrm{g} ; 48 \mathrm{~h}$ & $283+/-111 \%$ \\
Ethanol 25mM; 48 h & $\Rightarrow$ & ALE $10 \mu \mathrm{g} ; 48 \mathrm{~h}$ & $168+/-60 \%$ \\
$\mathrm{H}_{2} \mathrm{O}_{2} 10 \mathrm{mM} ; 24 \mathrm{~h}$ & $\Rightarrow$ & ALE $100 \mu \mathrm{g} ; 24 \mathrm{~h}$ & $116+/-2 \%$ \\
$\mathrm{H}_{2} \mathrm{O}_{2} 5 \mathrm{mM} ; 24 \mathrm{~h}$ & $\Rightarrow$ & ALE $100 \mu \mathrm{g} ; 24 \mathrm{~h}$ & $263+/-92 \% * *$ \\
$\mathrm{H}_{2} \mathrm{O}_{2} 1 \mathrm{mM} ; 24 \mathrm{~h}$ & $\Rightarrow$ & ALE $100 \mu \mathrm{g} ; 24 \mathrm{~h}$ & $107+/-12 \%$ \\
DMSO 5\%; $48 \mathrm{~h}$ & $\Rightarrow$ & ALE $100 \mu \mathrm{g} ; 48 \mathrm{~h}$ & $100+/-12 \%$ \\
DMSO 5\%; $48 \mathrm{~h}$ & $\Rightarrow$ & ALE $10 \mu \mathrm{g} ; 48 \mathrm{~h}$ & $97+/-7 \%$ \\
DMSO 3.5\%; $48 \mathrm{~h}$ & $\Rightarrow$ & ALE $100 \mu \mathrm{g} ; 48 \mathrm{~h}$ & $137+/-6 \% * *$ \\
DMSO 3.5\%; $48 \mathrm{~h}$ & $\Rightarrow$ & ALE $10 \mu \mathrm{g} ; 48 \mathrm{~h}$ & $101+/-4 \%$ \\
\hline
\end{tabular}


TABLE II - Influence of artichoke extract (ALE, $100 \mu \mathrm{g} / \mathrm{mL}$ ) in pre-, post- and cotreatment experiments with ethanol (50 mM) on relative gene expression on cytochromes CYP1A2 and CYP3A4 by quantitative real time PCR (TaqMan ${ }^{\circledR}$ assay), normalized to the house keeping gene GAPDH and untreated controls. $\Rightarrow$ : followed by treatment with compounds indicated

\begin{tabular}{lcccc}
\hline Treatment of HepG2 cells & & & CYP1A2 & CYP3A4 \\
\hline Ethanol $50 \mathrm{mM} ; 1 \mathrm{~h}$ & $\Rightarrow$ & ALE $100 \mu \mathrm{g} ; 23 \mathrm{~h}$ & 3.3 & 1.0 \\
Control experiment: Ethanol $50 \mathrm{mM} ; 1 \mathrm{~h}$ & $\Rightarrow$ & Medium only; 23 h & 3.0 & 2.5 \\
ALE $100 \mu \mathrm{g} ; 23 \mathrm{~h}$ & $\Rightarrow$ & Ethanol $50 \mathrm{mM} ; 1 \mathrm{~h}$ & 7.1 & 1.7 \\
Control experiment: Medium only; 23 h & $\Rightarrow$ & Ethanol $50 \mathrm{mM} ; 1 \mathrm{~h}$ & 6.2 & 1.0 \\
Ethanol $50 \mathrm{mM} ; 24 \mathrm{~h}$ & + & ALE $100 \mu \mathrm{g} ; 24 \mathrm{~h}$ & 29.8 & 3.9 \\
Control experiment: Medium & + & ALE $100 \mu \mathrm{g} ; 24 \mathrm{~h}$ & 1.8 & 0.7 \\
\hline
\end{tabular}

of cells with ethanol $50 \mathrm{mM}$ and ALE $100 \mu \mathrm{g} / \mathrm{mL}$ ). Gene expression was monitored for GST, GPX, GSR, GGT1, CYP1A2 and CYP3A4 and all values were related to the expression of the endogenous control GAPDH. As shown in Table II ethanol $50 \mathrm{mM}$ increased mRNA levels of CYP1A2 significantly. Pre- and posttreatment experiments with ALE revealed no big differences between the different test groups. In contrast to that, a thirtyfold increase in CYP1A2 was observed when coincubation was performed with ethanol plus ALE for a $24 \mathrm{~h}$ incubation period, indicating a strong influence of the artichoke-ethanol mixture on metabolic activity of the liver cells.

Significant influences of ethanol and/or ALE on expression of GST, GPX, GSR, GGT1 were not observed.

\section{CONCLUSIONS}

Extracts of artichoke are widely used for its choleretic and antihypercholesterinaemic effects. Within literature potential hepatoprotective effects are described, mainly using in vivo rat models (Gebhard, 1997). In vitro studies of hepatoprotective effects of artichoke extracts on cultured rat hepatocytes are shown against t-butylhydroperoxideinduced peroxidation of membrane lipids (Gebhard, 1997). Additionally cyanarin and caffeic acid were shown to reduce the carbontetrachloride-induced leakage of liver enzymes glutamic oxaloacetic transaminase and glutamic pyruvic transaminase (Adzet et al., 1987).

These data correlate with our investigations, indicating artichoke extract to have a direct effect on liver cells. Cell physiology of HepG2 cells is clearly up-regulated, with increased mitochondrial activity, leading to a higher energy status, inducing an increased protein synthesis and ending in a higher mitogenic activity. On the other side it is absolutely unclear which compounds from artichoke are responsible for these effects. In our investigations neither cynarin, chlorogenic acid or caffeic acid had any influence on the energy status of the cells. From that point of view artichoke extract specifications for preparations marketed with the indication "hepatoprotection" should not be standardized on these compounds. On the other side the flavones were shown to have strong inhibitory effects on liver cells with luteolin being a quite strong inductor of apoptosis by inhibition of topoisomerase II (Cantero et al., 2006). It seems interesting that luteolin-7-O-glucoside has significantly less toxic effects on HepG2 cells rather than the free aglycon luteolin, probably by a reduced absorption into the cells. For manufacture of commercial artichoke leaf extracts specifications therefore should focus on the amount of luteolin-glucoside beside that of the free aglycon.

Because the protein content of the cells is increased during incubation with artichoke extract it could be argued that also the metabolizing enzymes are upregulated unspecifically. This is clearly not the case when looking at the gene expression data of phase I and II enzymes expressed in HepG2 cells. Only one cytochrome mRNA, namely CYP1A2 is upregulated to a minor degree which is assessed to have no clinical relevance. All other enzymes monitored were slightly inhibited. This was also confirmed by biochemical determination of enzyme activity of GST which was significantly down-regulated by artichoke extract. If this enzyme inhibition has any clinical relevance this has to be investigated by in vivo studies in future.

Beside the direct effect of artichoke extract on HepG2 cells, pronounced cell protection by ALE was obvious. This was not only due to the known antioxidative effects of artichoke which were obvious in our studies against hydrogen peroxide and in previous studies (Gebhard, 1997) against t-BHP. Cell protection of ALE can also be discussed on ethanol-induced cell damage over metabolic pathways as well as against necrotic membrane disturbance, induced by compounds as DMSO. In general direct interactions between toxifying agents and ALE can be claimed as shown by the respective cotreatment experiments. On the other side also indirect effects are induced 
by artichoke extracts. The posttreatment experiments with ALE after damage with DMSO clearly confirmed the induction of repair mechanisms. A prophylactic application of artichoke extract does not seem to have an effect. On the other side it has to be pointed out that the positive effects of ALE against EtOH-, $\mathrm{H}_{2} \mathrm{O}_{2}$ - and DMSO-damaged liver cells is not due to a detoxificant effect but more due to an stimulation of metabolic capacity of the cells. Summarizing artichoke leaf extract may have the potential to be used as hepatoprotective agent. Prospective research will identify those compounds, which are responsible for described effects.

\section{ACKNOWLEDGEMENTS}

The HepG2 cell line was a generous gift from Prof. Dr. Mersch-Sundermann is acknowledged. Financial support by Lichtwer AG / Casellamed AG is acknowledged.

\section{REFERENCES}

ADZET, T.; CAMARASA, J.; LAGUNA, J. Hepatoprotective activity of polyphenolic compounds from Cynara scolymus against $\mathrm{CCl}_{4}$ toxicity in isolated rat hepatocytes. J. Nat. Prod., v.50, p.612-617, 1987.

BRAND, N.; Cynara. In: HÄNSEL, R.; SÉLLER, K., RIMPLER, H., SCHNEIDER, G., (Eds.). Hagers Handbuch der Pharmazeutischen Praxis, Drogen. 5. ed. Berlin, Heidelberg, New York: Springer Publishers, 1992. v.4, p.1117-1131.

CANTERO, G.; CAMPANELlA, C.; MATEOS, S.; CORTES, F. Topoisomerase II inhibition and high yield of endoreduplication induced by the flavonoids luteolin and quercetin. Mutagenesis, v.21, p.321-325, 2006.

DAUER, A.; HENSEL, A.; LHOSTE, F.; KNASMUELLER, S.; MERSCH-SUNDERMANN, V. Genotoxic and antigenotoxic effects of catechin and tannins from the bark of Hamamelis virginiana L. in metabolically competent, human hepatoma cells (HepG2) using single cell electrophoresis. Phytochem., v.63, p.199-207, 2003.

ESCOP Monograph - The Scientific Foundation for Herbal Medicinal Products. Cynarae folium - Artichoke leaf. 2.ed. New York: Thieme Publishers, 2003.

GEBHARD, R. Anticholestatic activity of flavonoids from artichoke (Cynara scolymus L.) and their metabolites. Med. Sci. Mon., v.7, supl.1, p.316-320, 2001.
GEBHARD, R. Antioxidative and protective properties of extracts from leaves of the artichoke (Cynara scolymus L.) against hydroperoxide-induced oxidative stress in cultured rat hepatocytes. Tox. Apl. Pharmacol., v.144, p.279-286, 1997.

GEBHARD, R. Artischockenextrakt - in vitro Nachweis einer Hemmwirkung auf die Cholesterolbiosynthese. Medizin Welt, v.46, p.348-350, 1995.

GEBHARD, R. Neue Erkenntnisse zur Wirkung von Artischockenextrakte. Z. Allgemeinmed., v.72, p.20-23, 1996.

HOFMANN, T.; DETERS, A.; MÜLLER, G.; STARK, T.; WITTSCHIER, N.; HENSEL, A. Occurence of N-Phenylpropenoyl-L-amino acids in different herbal drugs and influence on human keratinocytes, human liver cells and against adhesion of H. pylori to human stomach. Planta Med., v.73, p.142-150, 2007.

LOWRY, O.H.; NIRA, J.; ROSEBROUGH, N.J.; FARR, A.L.; RANDALL, R.J. Protein measurement with the Folin phenol reagent. J. Biol. Chem. v.193, p.265-275, 1951.

MAROS, T.; SERES-STRUMR, L.; RAIZ, G.; RETEJI, C.; KOVACS, V.V.; HINTS, M. Wirkung der Cynara scolymusExtrakte auf die Regeneration der Rattenleber Drug Res., v.18, p.884-886, 1968.

MARTIN, A.; CLYNES, M. Comparison of 5 microplate colorimetric assays for in vitro cytotoxicity testing and cell proliferation assays. Cytotechnology, v.11, p.9-58, 1993.

MATUSCHOWSKI, P.; GUMBINGER, H.G.; NAHRSTEDT, A.; WINTERHOFF, H. Testing of Cynara scolymus L. in the isolated perfunded rat liver. Planta Med., v. 63, p. 55$56,1997$.

MATUSCHOWSKI, P.; NAHRSTEDT, A.; WINTERHOFF, H. Pharmakologische Untersuchungen eines Frischpflanzenpresssaftes aus Cynara scolymus auf choleretische Wirkung. Z. Phytother, v.26, p.216-221, 2005.

MOSMANN, M. Rapid colorimetric assay for cellular growth and survival: applications to Proliferation and cytotoxicity assays. J. Immunol. Methods, v.65, p.55-63, 1983. 
PITTLER, M.H.; THOMPSON, C.J.; ERNST, E. Artichoke leaf extract for treating hypercholesterolaemia (Review). The Cochrane Database of Syst. Rev., volume?, Issue 3, pages?, 2002.

PORSTMANN, T.; TERNYK, T.; AVRAMEAS, S. Quantification of 5-bromo-2'-deoxyuridine into DNA: an enzyme immunoassay for the assessment of the lymphoid cell proliferative response. J. Immunol. Methods, v.82, p.169-179, 1985.

PREZIOSI, P. Dal Cynara scolymus allacito 1,4-dicaffeilchinico. Il Fármaco (ed. Sc.), v. 17, p. 701-745, 1962.

STOEV, S.D.; STEFANOV, M.; DENEB, S.; RADIC, B.;, DOMINAN, A.M.; PERAICA, M. Experimental mycotoxicosis in Chickens induced by ochratoxin A and penicillic acid and intervention with natural plant extracts. Vet. Res. Común., v.28, p.724-46, 2004.
SUZUKI, T.; ONOGAWA, T.; ASANDO, N.; MIZUTAMARI, H.; MAKKAICHI, T.; TANEMOTO, M.; et al. Identification and characterization of novel rat and human gonad-specific organic anion transporters. Mol. Endocrinol., v.17, p.1203$1215,2003$.

WITTEMER, S.M.; PLOCH, M.; WINDECK, T.; MÜLLER, S.C.; DREWELOW, B.; DERENDORF, H.; et al.Bioavailability and pharmacokinetic properties of caffeoylquinic acids and flavonoids after oral administration of artichocke leaf extracts in human. Phytomedicine, v.12, p.25-38, 2005.

WOJCICKI, J. Effect of 1,5-dicaffeylquinic acid (cynarine) on colesterol levels in serum and liver of acute ethanol-induced rats. Drug Alc. Dep., v.3, p.143-145, 1978.

Received for publication on $22^{\text {th }}$ december 2008 Accepted for publication on $18^{\text {th }}$ may 2009 